\title{
TINGKAT KEADILAN DISTRIBUTIF DAN KEADILAN INTERAKSIONAL KOMPENSASI TERHADAP KEPUASAN KERJA PADA RUMAH SAKIT PKU MUHAMMADIYAH BIMA
}

\author{
Jaenab ${ }^{1}$, Ety Kurniawati ${ }^{2}$ \\ 'Sekolah Tinggi Ilmu Ekonomi (STIE) Bima \\ Email : jaenab.stiebima@gmail.com \\ ${ }^{2}$ Sekolah Tinggi Ilmu Ekonomi (STIE) Bima
}

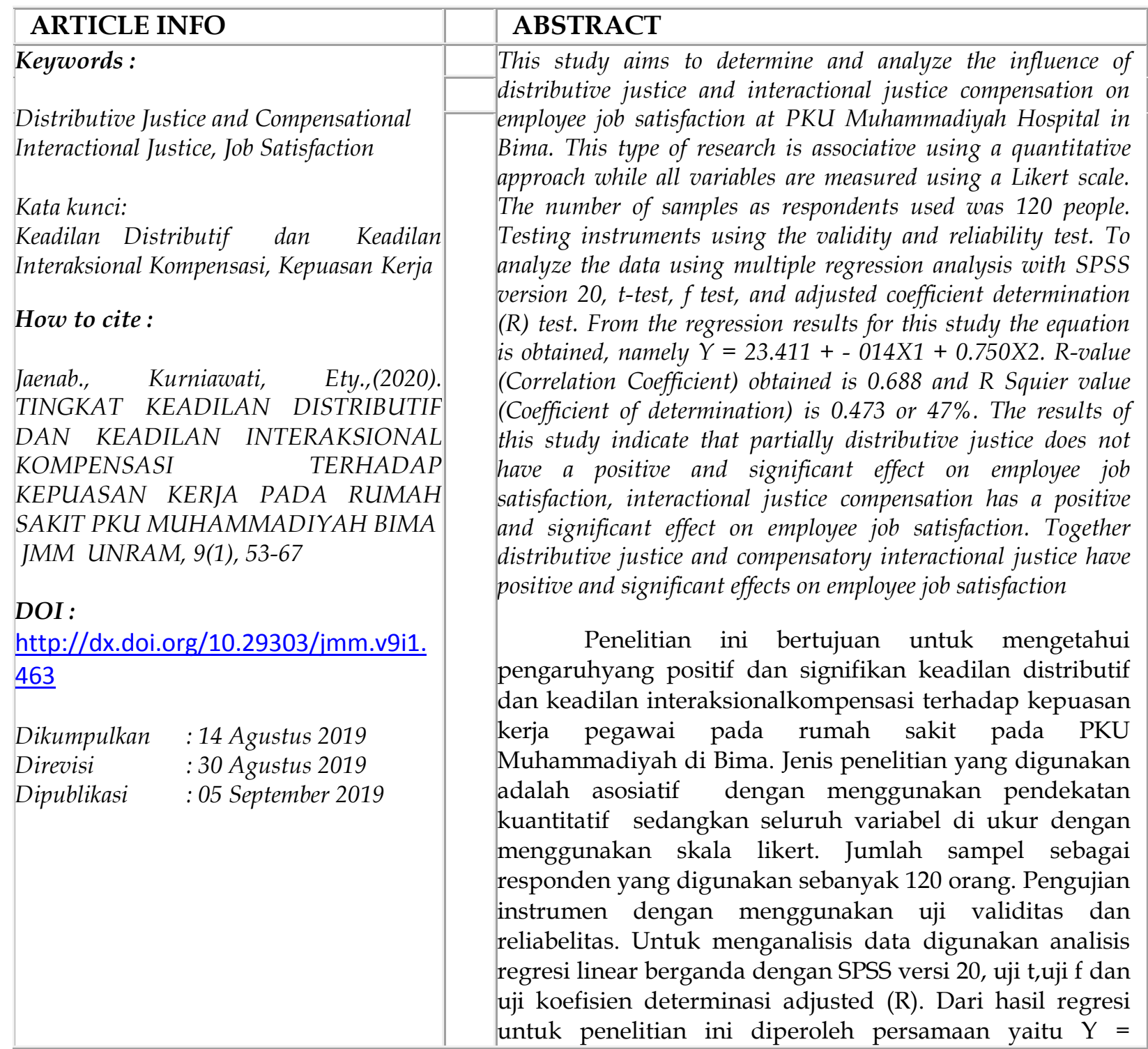




\begin{tabular}{|l|l|}
\hline $\begin{array}{l}\text { 23,411+- 014X1+0,750X2. Nilai R (Koefisien Korelasi) yang } \\
\text { diperoleh sebesar 0,688 dan nilai R Squer (Koefisien } \\
\text { determinasi) sebesar 0,473 atau 47\%. Hasil dalam } \\
\text { penelitian ini menunjukkan bahwa secara parsial keadilan } \\
\text { distributif tidak berpengaruh positif dan signifikan } \\
\text { terhadap kepuasan kerja pegawai, keadilan } \\
\text { interaksionalkompensasi berpengaruh positif dan } \\
\text { signifikan terhadap kepuasan kerja pegawai. Secara } \\
\text { bersama-sama terbukti bahwakeadilan distributif dan } \\
\text { keadilan interaksionalkompensasi berpengaruh positif dan } \\
\text { signifikan terhadap kepuasan kerja pegawai. }\end{array}$ \\
\hline Copyright @ 2020 JMM UNRAM. All rights reserved.
\end{tabular}

\section{PENDAHULUAN}

Sumber dari tingkat kreatifitas inovasi dan produktifitas pegawai adalah tingkat kepuasan kerja pegawai. Semakin meningkatnya kepuasan kerja pegawai akan mendorong para pegawai untuk menciptakan inovasi baru dan meningkatkan jumlah barang atau jasa.Kompensasi (remunerasi) merupakan faktor paling penting bagi daya saing badan usaha milik Negara (BUMN) dan badan usaha milik swasta (BUMS) seperti Rumah Sakit PKU Muhammadiyah Bima yang merupakan amal usaha Muhammadiyah dalam bidang kesehatan dan kemasyarakatan sebagai salah satu upaya untuk mencapai tujuan dakwah yang dikembangkan oleh Muhammadiyah.

Ketidakadilan di dalam organisasi merupakan salah satu bentuk praktik disfungsional organisasi yang bedampak pada suasana kerja yang tidak nyaman di dalam organisasi. Ketidakadilan dan keadilan merupakan hal yang sangat diperhatikan karyawan terkait dengan proses yang bersifak transaksional dalam organisasi. Salah satu kebijakan organisasi atau perusahaan yang menjadi perhatian penting karyawan adalah kebijakan yang terkait dengan karir didalam perusahaan (Tjahjono dalam Majang Palupi, 2014). Persepsi karyawan mengenai ketidakadilan tersebut akan mendorong mereka untuk melakukan balas dendam (perilaku retaliasi) terhadap organisai tempat mereka bekerja (Hollinger, at al dalam Majang palupi, 2014). Salah satu bentuk perlawanan karyawan atas ketidakadilan manejerial misalnya pencurian, penundaan pekerjaan menyebabkan rekan kerja juga menunda pekerjaan, terlambat dating rapat dan bekerja tidak seharusnya.Sebaliknya, apabila karyawan mempersepsikan bahwa kontribusi mereka terhadap organisasi seimbang dengan imbalan yang terima, maka para karyawan cenderung meberikan reaksi-reaksi positif seperti kepuasan kerja.

Kepuasan kerja adalah sikap seseorang mengenai pekerjaan apa yang mereka kerjakan dalam sebuahperusahaan atau organisasi untuk pekerjaan didasarkan pada hasil yang diinginkan Mosadeghrad (dalam krisnayanti, at el, 2015 ) sebuah organisasi dimana mereka melakukan pekerjaanini atau reaksi efektif pegawai.

Masalah yang sering muncul saat ini yang menyebabkan situasi yang tidak kondusif di lingkungan organisasi seperti masih adanya keluhan beberapa pegawai yang merasa tidak adil dalam pembagian kerja shift yaitu (pagi, siang dan malam) dengan gaji yang sama tetapi beban kerja lebih dari tupoksinya, adanya pegawai yang terlambat tetapi gajinya dipotong walaupun dia bekerja lembur dan hubungan antara karyawan yang tidak serasi. Permasalahan lain juga hubungan antar pegawai yang 
tidak serasi, kemudian dilihat dari segi promosi jabatan untuk menempati posisi jabatan yang lebih tinggi dirasa masih sangat kurang dikarenakan persaingan antar sesama pegawai yang cukup ketat.

Kepuasan kerja pegawai rumah sakit sekarang ini perlu mendapat perhatian yang serius pimpinan organisasi karena adanya kecenderungan organisasi tidak berlaku adil dalam memberikan kompensasi pada pegawai yang bekerja lebih dari tupoksinya bisa dilihat dari jabatan, beban kerja yang berlebih,dan jam kerja dan lembur, apabila ada pekerja yang belum diselesaikan tetapi kompensasinya sama. Kepuasan merupakan perasaan positif atau negatif seseorang terhadap pekerjaannya, pegawai akan merasa puas apabila adanya keadilan dalam pembagian jam kerja secara adil.

Dengan adanya masalah diatas, diharapkan pimpinan harus menciptakan keadialan kompensasi agar pegawai berpeluang untuk membangun tumbuhnya kerjasama yang menyenangkan, perasaan positif pegawai sehingga akan mendorong kepuasan kerja sehingga berdampak kepada kualitas layanan yang akan di berikan oleh pegawai lebih baik lagi. Keadilan distributif kompensasi penting untuk membagi informasi secara terbuka agar alokasi keputusan dibuat, memgikuti prosedur yang dibuat.Pimpinan harus senantiasa memonitoring kepuasan kerja, karena hal itu mempengaruhi tingkat absensi, perputaran tenaga kerja, semangat kerja dan keluhankeluhan.Oleh kerana itu perlu di teliti dampak lain Tingkat keadilan distributif dan keadilan interaksionalkompensasi terhadap kepuasan kerja pada Rumah sakit PKU Muhammadiyah Bima.

Rumusan masalah ini untuk menguji Apakah keadilan distributifdan keadilan interaksional kompensasi berpengaruh positif dan signifikan terhadap kepuasan kerja pegawai pada Rumah sakit PKU Muhammadiyah Bima.

Tujuan dari penelitian ini untuk mengetahui keadilan distributifdan keadilan interaksional kompensasi berpengaruh positif dan signifikan terhadap kepuasan kerja pegawai pada Rumah sakit PKU Muhammadiyah Bima.

Manfaat penelitian ini yaitu diharapkan dapat dijadikan sebagai bahan pertimbangan dan masukkan terhadap pihak atau manajemenpada Rumah sakit PKU Muhammadiyah Bima, berkaitan dengan keadilan distributif dan keadilan interaksional kompensasidan kepuasan kerja pegawai Rumah sakit PKU Muhammadiyah Bima yang dapat membantu organisasi sesuai dengan visi dan misi. Diharapkan pula penelitian hasil penelitian ini dapat menambah khasanah ilmu pengetahuan terkait keadilan interaksionalkompensasi dan keadilan interaksional terhadap kepuasan kerja pegawai pada Rumah sakit PKU Muhammadiyah Bima.

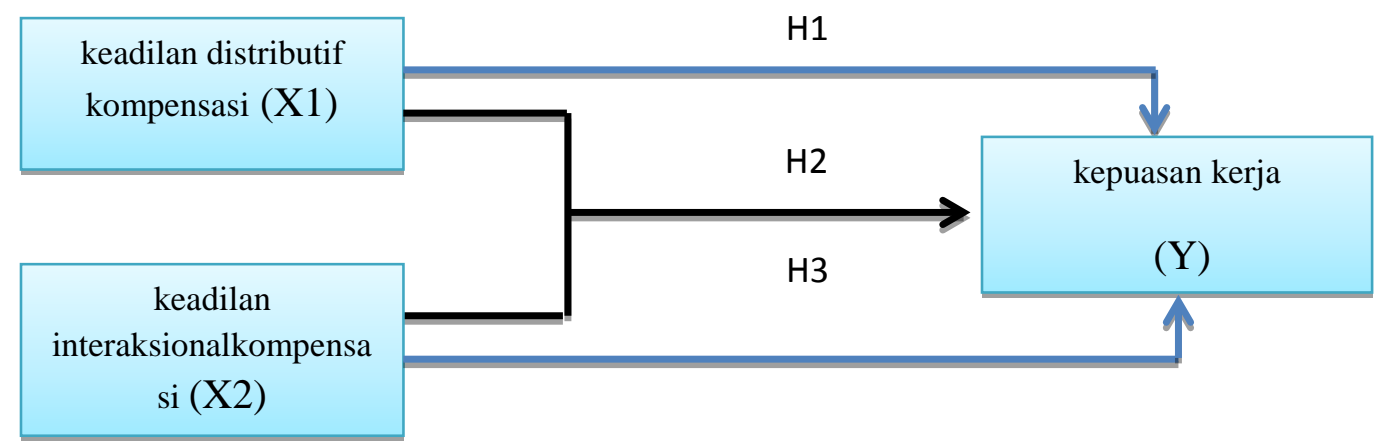

Hipotesis:

Gambar 1.Kerangka Konseptual 
$\mathrm{H} 1$ = Keadilan distributif berpengaruh positif dan signifikan terhadap kepuasan kerja padaRumah sakit PKU Muhammadiyah Bima.

$\mathrm{H} 2$ = Keadilan interaksionalkompensasi berpengaruh positif dan signifikan terhadap kepuasan kerja pada Rumah sakit PKU Muhammadiyah Bima.

$\mathrm{H} 3$ = Keadilan distributif dan keadilan interaksionalkompensasi berpengaruh positif dan signifikan terhadap kepuasan kerja padaRumah sakit PKU Muhammadiyah Bima.

\subsection{Kepuasan Kerja}

\section{TINJAUAN PUSTAKA}

Kepuasan kerja (job satisfacsion) adalah keadaan emosional yang menyenangkan atau tidak menyenangkan dengan mana para pegawai memandang pekerjaan mereka.Kepuasan kerja mencerminkan perasaan seseorang terhadap pekerjaannya.Ini nampak positif karyawan terhadap pekerjaannya dan segala sesuatu yang dihadapi di lingkungan kerjanya.Manajer harus senantiasa memonitoring kepuasan kerja, karena hal itu mempengaruhi tingkat absensi, perputaran tenaga kerja, semangat kerja dan keluhankeluhan.Kepuasan kerja adalah keadaan emosional yang positif yang merupakan hasil dari evaluasi pengalaman kerja seseorang (Rahmayanti, at el, 2016).Tujuan dari organisasipublik adalahefisiensidanefektivitas dan termasuk terciptanya nilai-nilai kesetaraan, transparansi, dan keadilan di dalam organisasi, (Jumari dkk, 2013).

Banyak riset yang menunjukkan kepuasankerjamenjadimasalah yangcukupmenarikdanpenting,karena terbuktibesarmanfaatnya bagi kepentingan individu, industri dan masyarakat. Bagi individu, penelitian tentangsebab-sebab dansumber-sumber kepuasankerjamemungkinkan timbulnyausaha-usaha peningkatan kebahagiaanhidupmereka (Rahmayanti, at el, 2016).Kepuasan kerja terjadi apabila kebutuhan-kebutuhan individu sudah terpenuhi dan terkait dengan derajat kesukaan dan ketidaksukaan pegawai (Sari,E, 2009).

Oleh karena menggambarkan perasaan, maka mengacu komponen sikap, kepuasan kerja merupakan komponen afeksi.Sikap atau afeksi tersebut terbentuk sebagai hasil evaluasi terhadap pengalaman aspek-aspek pekerjaannnya.Lebih lanjut, karena kepuasan kerja merupakan afeksi, maka keberadaanya dapat mempengaruhi perilaku lebih lanjut, baik intensitas atau arahnya atau pilihan-pilihan (Rahmayanti, at el, 2016).

Kepuasan kerja karyawan yang tinggi sangat penting untuk manajer yang percaya bahwa suatu organisasi memiliki tanggung jawab untuk memberikan karyawan pekerjaan yang menantang dan menguntungkan (Widyaningrum, 2010). Kepuasan kerja dapat ditinjau dari dua sisi, dari sisi karyawan, kepuasan kerja akan memunculkan perasaan menyenangkan dalam bekerja, sedangkan dari sisi perusahaan, kepuasan kerja akan meningkatkan produktivitas, perbaikan sikap dan tingkah laku karyawan dalam memberikan pelayanan prima (Rahmayanti, at el, 2016).

\subsection{Keadilan Distributif}

Teori keadilan dalam organisasi merupakan refinement dari teori keadilan milik adams, 1965 (Rahmayanti, 2016), yang tergolong dalam teori motivasi kontemporer mengenai motivasi kerja. Teori keadilan menyatakan bahwa manusia mempunyai pikiran, perasaan, dan pandangan yang mempengaruhi motivasi kerja mereka.Secara historis, teori keadilan berfokus keadilan distributive yaitu keadilan dari jumlah imbalan antara-antara individu dalam satu organisasi.

Penelitian keadilan distributif dalam organisasi saat ini memfokuskan terutama pada persepsi seseorang terhadap adil tidaknya outcome (hasil) yang mereka terima, yaitu 
penelaian mereka terhadap kondisi akhir dari proses alokasi ( Lihat Tjahjono, 2008, dan 20011, Majang Palupi, 2014). Keadilan distributif adalah keadilan yang berkaitan dengan distribusi sumber daya dan kriteria yang digunakan untuk menentukan alokasi sumber daya tersebut.Keadilan jenis ini menyangkut masalah seseorang terhadap adil tidaknya karir yang mereka terima.

Keadilan distributif menyatakan bahwa hasil individu-individu dalam organisasi akan mengevaluasi distributif, yang sering digunakan adalah hak menurut keadilan dan kewajaran (Cohen dan Gilliland dalam majang Palupi, 2014). Teori kewajaran (equity theory), mengatakan bahwa imbalan-imbalan organisasional harus didistribusikan sesuai dengan tingkat kontribusi individual (lihat cowherd dan Levine berhubungan dengan persepsi karyawan terhadap kewajaran dan keseimbangan antara masukan-masukan yang mereka berikan terhadap imbalan-imbalan yang mereka terima seimban, mereka merakasan adanya kewajaran (equity). Di sisi lain, ketidakseimbangan rasio antara masukan dan imbalan menggiring mereka pada persepsi akan adanya ketidakwajaran (cowherd dan lewine, dalam majang palupi, 2014). Diperkuat oleh Hasmarini (2008) dalam Irawan dan Sudarma (2016) menemukan bahwa kenaikan gaji atau bonus yang lebih cenderung dipersepsikan dengan adanya kenaikkan hasil yang lebih adil dan lebih memuaskan. Keadilan distributif adalah keadilan yang paling sering dinilai dengan dasar keadilan hasil, yang menyatakan bahwa karyawan seharusnya menerima upah/gaji yang sesuai dengan pemasukan dan pengeluaran mereka secara relatif dengan perbandingan referen/lainnya

Keadilan distributif mengukur persepsi pegawai dimana pekerja di berikan penjelasan yang jujur dari setiap keputusan. Beberapa studi sebelumnya telah menggunakan skala ini dengan hasil yang memuaskan (Puryana, 2017), Dengan Indikator: 1) Persamaan, 2) Kelayakan, 3). Kontribusi 4) Kinerja.

\subsection{Keadilan Interaksional kompensasi}

Keadilan interaksional berfokus pada persepsi individu terhadap kualitas perlakuan interpersonal yang diterima selama berlakunya prosedur organisasi.. Dua elemen yang penting persepsi keadilan interkasional adalah apakah alasan yang mendasari sumber daya kepalokasi jelas,jujur dan cukup menjelaskan kepada pihak yang terkena dampak dan apakah bertanggung jawab untuk melaksanakan keputusan. Keadilan interkasional yang memusatkan perhatian bagaimana memperlakukan orang lain dengan penuh hormat dan martabat. Greenberg (dalam Sancoko dan Panggabean, 2015) yang menyatakan bahwa keadilan interkasional mempunyai dua kompenen yang berdiri sendiri yaitu keadilan interpersonal dan keadilan informasional.Bedasarkan uraian diatas dapat disimpulkan bahwa dua kontruk diatas sudah teruji validitasnya.Seperti yang telah diuraikan ditas, keadilan iteraksional di kelola dengan baik karena memberi dampak positif terhadap sikap dan perilaku.

Keadilan interaksional mengukur persepsi pegawai dimana pekerja di perlakukan dengan rasa hormat dan bermartabat (Puryana, 2017), Dengan indikator: 1). Kejujuran, 2). Pembenaran, 3). Masuk akal, 4). Tepat waktu 5).Spesifik.

2.4 Hubungan keadilan distributif terhadap kepuasan kerja

Organisasi yang adil dalam hal distributif kepada pegawai berupa keadilan dalam pemberian reward, achievement dan resources kepada pegawai tentu saja akan meningkatkan kepuasan kerja pegawai di dalam organisasi.Hasil penelitian (Rahmayanti, at el, 2016) Keadilan distributif, salah satunya berupa kejelasanjenjangkarir diorganisasiperluagar pegawai tidak lagi mencari peluang kerja di tempatlain.

2.5 Hubungan keadilan interaksional kompensasi terhadap kepuasan kerja 
Organisasi yang adil dalam hal interaksional berupa pemeliharaan hubungan kerja yang baik antar pegawai, para pimpinan, dan manajemen akan menumbuhkan kepuasan kerja pegawai berupa peningkatan kerja. Keadilan interaksionalsalah satunya berupa interaksiantaraatasan dan pegawaiharus terusdijalinagar organisasi dapatberjalandengan semakin baik (Rahmayanti, at el, 2016).

\subsection{Hubungan keadilan distributif dan keadilan interaksional kompensasi terhadap} kepuasan kerja

Menurut penelitian kadaruddin 2012(dalam Rahmayanti, at el, 2016), sukses atau tidaknya suatu organisasi tergantung pada kemampuan organisasi dalam memberikan kepuasan kerja terhadap pegawainya.Kepuasan kerja dapat dicapai dengan memelihara hubungan kerja yang baik antar pegawai, para pimpinan, dan petugas dibagian kepegawaian.Hal ini di buktikan oleh penelitian (Sari,E, 2009) menunjukkan bahwa menciptakan kompensasi dan proses balas jasa yang baikterhadapkaryawanakanlebihmendorongkepuasan kerjakaryawan.

\section{a. Tinjauan Penelitian Terdahulu}

Krisnayanti dan Riana, (2015) meneliti Pengaruh keadilan organisasi terhadap kepuasan kerja karyawan hasil penelitian yang diperoleh pada penelitian ini 1) Keadilan distributif berpengaruh positif dan signifikan terhadap kepuasan kerja 2). Keadilan interaksional berpengaruh positif dan signifikan terhadap kepuasa kerja. 3) keadilanprosedural berpengaruh positif dan signifikan terhadap kepuasan kerja dan Keadilan interaksional berpengaruh positif dan signifikan terhadap kepuasan kerja.

Putra (2018) pengaruh keadilan organisasi terhadap kepuasan kerja dan komitmen organisasional di hotel rama phala ubud. Beberapa temuan empiris hasil penelitian menunjukkan bahwa keadilan organisasiberpengaruh positif dan signifikan terhadap kepuasan kerja.Kepuasan kerja berpengaruh positif dan signifikan terhadap komitmen organisasi, selanjutnya kepuasan kerja diterima sebagai variabel intervening dalam memediasi pengaruh keadilan organisasi terhadap komitmen organisasional.

Atmojo dan Tjahjono, 2016.Pengaruh keadilan distributif dan prosedural konpensasi terhadap kepuasan kerja dan kinerja paramedis di rumah sakit.Hasil penelitian ini menunjukkan bahwa keadilan prosedural kompensasi berpengaruh positif pada kepuasan kompensasi paramedis. Demikian pula keadilan prosedural kompensasi juga berpengaruh positif pada kinerja paramedic dirumah sakit.

\section{METODE PENELITIAN}

Penelitian ini dilakukan pada pegawaiRumah sakit PKU Muhammadiyah Bima yang berlokasi Jln. Gajahmada.Populasi dalam penelitian ini seluruh pegawaiyang ada pada Rumah sakit PKU Muhammadiyah Bima sebanyak 120 pegawai tetap dan kontrak.Tehnik pengambilan sampel yang digunakan dalam penelitian ini adalah sampel jenuh.

Tehnik pengumpulan data dilakukan melalui: penelitian dengan observasi, Kuesioner dan dukumentasi untuk mendapatkan data yang berhubungan pada keadilan distributif kompensasi, keadilan interaksional kompensasi dan kepuasan kerja dengan melihat langsung Rumah sakit PKU Muhammadiyah Bima. Wawancara, dilakukan langsung HRD dan penyebaran kuesioner kepada seluruh pegawai sebanyak 120 orang responden pada Rumah sakit PKU Muhammadiyah Bima.

\section{Definisi operasional variabel}

1. Keadilan Distributif 
Keadilan distributif adalah persepsi pegawai dimana pekerja di berikan penjelasan yang jujur dari setiap keputusan. Beberapa studi sebelumnya telah menggunakan skala inidengan hasil yang memuaskan.Dengan Indikator (Puryana, 2017): 1) Persamaan, 2) Kelayakan, 3). Kontribusi 4) Kinerja.

2. Keadilan Interaksional kompensasi

Keadilan interaksional adalah persepsi pegawaidimana pekerja di perlakukan dengan rasa hormat dan bermartabat. Dengan indikator (Puryana, 2017): 1). Kejujuran, 2). Pembenaran, 3). Masuk akal, 4). Tepat waktu 5). Spesifik

3. Kepuasan kerja (job satisfacsion) adalah keadaan emosional yang menyenangkan atau tidak menyenangkan dengan mana para pegawai memandang pekerjaan mereka. JobDescriptionIndex (JDI) dapat digunakan untuk mengukur kepuasan kerja dari limahalyaitu gaji, pekerjaan itu sendiri, promosi, supervisi, dan rekan kerja. (Nadiri, 2010).

Untuk menganalisis data pada penelitian ini digunakan regresi linear berganda yang bertujuan untuk mengetahui pengaruh keadilan distributif dan keadilan interaksional kompensasi terhadap kepuasan kerja pegawai padaRumah sakit PKU Muhammadiyah Bima. Persamaan regresi linear berganda dalam penelitian ini adalah: $Y=\alpha+\beta_{1} X_{1}+\beta_{2} X_{2}$.

\section{HASIL PENELITIAN DAN PEMBAHASAN}

\subsection{Hasil uji Instrumen}

Data yang digunakan adalah data yang berasal dari jawaban kuesioner yang dikumpulkan dengan cara menkuantitatifkan dari informasi yang bersifat kualitatif.

\section{Uji validitas}

Tabel 1. Hasil uji validitas

\begin{tabular}{|c|c|c|c|c|}
\hline $\begin{array}{c}\text { r. Hitung } \\
\text { Variabl X1 }\end{array}$ & $\begin{array}{l}\text { r. Hitung } \\
\text { Variabl X2 }\end{array}$ & $\begin{array}{l}\text { r. Hitung } \\
\text { Variabl Y }\end{array}$ & r. Tabel & Ket. \\
\hline$(X 1.1)$ 0,712 & $(X 2.1) 0,536$ & (Y1) 0,361 & 0,30 & Valid \\
\hline (X1.2) 0,843 & $(X 2.2) 0,457$ & (Y2) 0,324 & 0,30 & Valid \\
\hline (X1.3) 0,867 & $(X 2.3) 0,661$ & (Y3) 0,594 & 0,30 & Valid \\
\hline (X1.4) 0,820 & $(X 2.4) 0,697$ & (Y4) 0,741 & 0,30 & Valid \\
\hline (X1.5) 0,908 & $(X 2.5)$ 0,762 & (Y5) 0,328 & 0,30 & Valid \\
\hline (X1.6) 0,733 & $(X 2.6) 0,707$ & (Y6) 0,423 & 0,30 & Valid \\
\hline (X1.7) 0,889 & $(X 2.7) 0,721$ & (Y7) 0,745 & 0,30 & Valid \\
\hline \multirow[t]{6}{*}{ (X1.8) 0,595 } & $(X 2.8) 0,770$ & (Y8) 0,543 & 0,30 & Valid \\
\hline & $(X 2.9) 0,577$ & (Y9) 0,566 & 0,30 & Valid \\
\hline & $(X 2.10) 0,586$ & (Y10) 0,526 & 0,30 & Valid \\
\hline & & (Y11) 0,383 & 0,30 & Valid \\
\hline & & (Y12) 0,657 & 0,30 & Valid \\
\hline & & (Y13) 0,663 & 0,30 & Valid \\
\hline
\end{tabular}

Sumber Data diolah, 2019

Berdasrkan tabel 1. Dapat diketahui bahwa semua koefisien korelasi dari indikator indikator variabel penelitian yang telah diujikan memiliki nilai lebih besar dari 0,30 ( $\mathrm{r}>$ 0,30 dan Sig < 0,05. Hal ini dapat menunjukkan bahwa semua indikator-indikator pada penelitian ini dapat dinyatakan valid. 


\section{Uji Reliabilitas}

Tabel 2. Hasil Uji Reliabilitas

\begin{tabular}{llll}
\hline No & \multicolumn{1}{c}{ Variabel } & Cronbach's Alpha & \multicolumn{1}{c}{ Ket. } \\
\hline 1 & keadilan distributif kompensasi & 0,919 & Reliabel \\
2 & Keadilan interaksional kompensasi & 0,847 & Reliabel \\
3 & Kepuasan kerja & 0,791 & Reliabel \\
\hline
\end{tabular}

Sumber Data diolah, 2019

Hasil uji bahwa masing-masing nilai Cronbach's alpha pada tiap instrument penelitian lebih besar dari 0,6 (Cronbach's alpha> 0,6). Dengan demikian hasil tersebut menunjukkan bahwa semua instrument terbukti reliabel, sehingga dapat digunakan untuk melakukan penelitian.

\subsection{Uji Asumsi Klasik}

Uji asumsi klasik dilakukan untuk memenuhi penggunaan regresi linear berganda.

\subsubsection{Uji Normalitas}

Uji ini dilakukan untuk mengetahui apakah nilai residual tersebar normal atau tidak. Jika nilai sig. (p-value) > 0,05 maka Ho diterima yang artinya normalitas terpenuhi. Hasil uji normalitas dapat dilihat p-value 0,623.> 0,05, maka dapat disimpulkan bahwa data terdistribusi normal Normal P-P Plot of Regression Standardized Residual

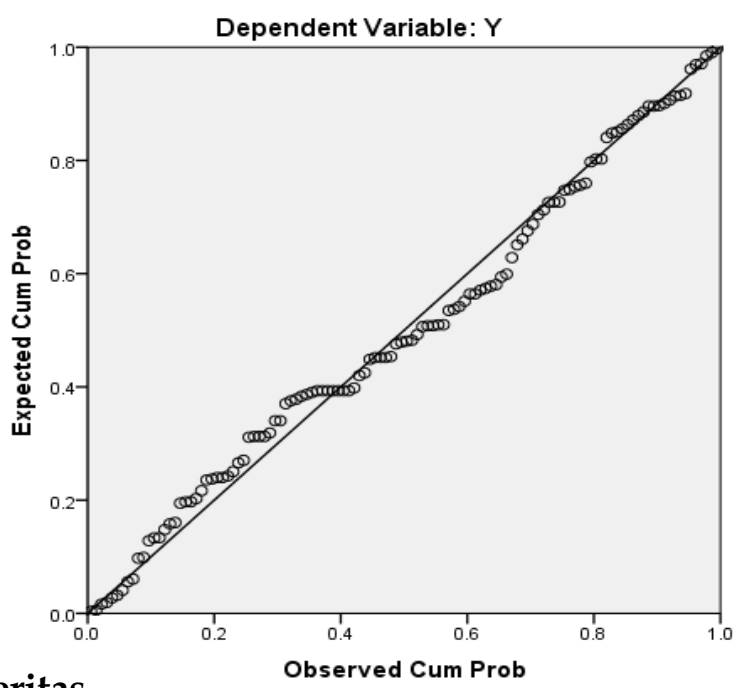

\subsubsection{Uji multikolonieritas}

Uji multikolonieritas dapat pula dilakukan dengan cara membandingkan nilai tolerance $\geq 0,10$ atau VIP $\leq 10$ maka di indikasikan bahwa model regresi tidak memiliki gejala multikolonieritas.

Tabel 3 Hasil uji multikolonieritas

\begin{tabular}{|c|c|c|}
\hline Variabel & VIF & Keterangan \\
\hline $\begin{array}{c}\text { Keadilan distributif } \\
\text { Keadilan interaksional } \\
\text { kompensasi }\end{array}$ & 1,130 & Tidak ada multikolinieritas \\
\hline
\end{tabular}




\subsubsection{Uji Heterokedastitas}

Uji Heterokedastitas bertujuan untuk mengetahui apakah terjadi ketidaksamaan nilai simpangan residual akibat besar kecilnya nilai salah satu variable bebas satu pengamata kepengamatan yang lainnya. Jika nilai signifikan lebih besar dari 0,05 maka tidak terjadi heterokedastitas sehingga model regresi yang baik adalah homoskedasitas atau tidak terjadi Heterokedastitas (Ghozali, 2009).

Scatterplot

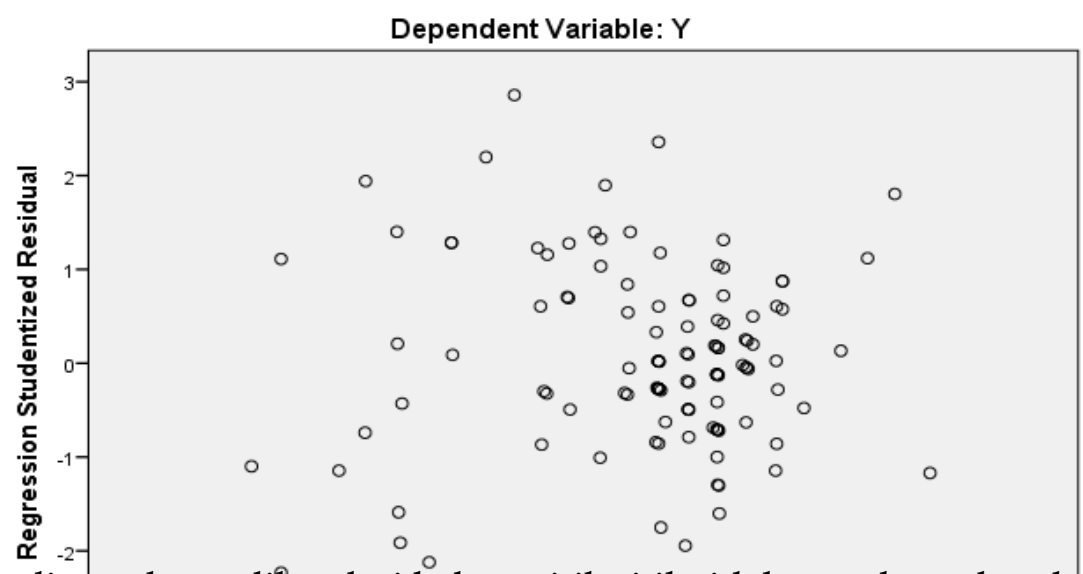

Dari output diatas dapat diketahui bahwa titik-titik tidak membentuk pola yang jelas, dan titik-titik menyebar diatas dan dibawah angka 0 pada sumbu Y. Jadi dapat disimpulkan bahwa tidak terjadi heterokedastisitas dalam model regresi penęititian ini.

\subsubsection{Uji autokorelasi}

Regression Standardized Predicted Value

Pengujian autokorelasi dilakukan dengan uji durbin Watson dengan membandingkan nilai durbin Watson hitung (d) dengan durbin Watson tabel. Nilai dw dapat dilihat dalam tabel 4 model summary berikut:

\section{Tabel 4 Durbin watson \\ Model Summaryb}

\begin{tabular}{|l|r|r|r|}
\hline \multirow{2}{*}{ Model } & \multicolumn{2}{|c|}{ Change Statistics } & \multirow{2}{*}{ Durbin-Watson } \\
\cline { 2 - 3 } & df2 & Sig. F Change & \\
\hline 1 & $117 \mathrm{a}$ & .000 & 1.782 \\
\hline
\end{tabular}

Sumber data: Data diolah, 2019

Dari tabel diatas diketahui bahwa nilai dw sebesar 1,782 selain itudari tabel durbin Watson tabel nilai du sebesar 1,6684 dan nilai 4-du sebesar 2,239. Sehingga diperoleh du < $\mathrm{dw}<4$ - du yakni 1,6684<1,782 $<2,239$ yang berarti tidak terjadi autokorelasi secara positif dan negative dalam penelitian ini bebas autokorelasi.

\subsection{Hasil Analisis Regresi Linier Berganda}

Analisis regresi linier berganda digunakan untuk mengetahui pengaruh variable bebas terhadap variabel terikat. Hasil analisis regresi linier berganda dapat dilihat tabel 5 berikut ini: 
Tabel 5 Hasil analisis regresi linear berganda

\begin{tabular}{|c|c|c|c|c|c|c|}
\hline & \multirow[t]{2}{*}{ Model } & \multicolumn{2}{|c|}{$\begin{array}{l}\text { Unstandardized } \\
\text { Coefficients }\end{array}$} & \multirow{2}{*}{$\begin{array}{c}\begin{array}{c}\text { Standardize } \\
\mathrm{d}\end{array} \\
\text { Coefficients }\end{array}$} & \multirow[t]{2}{*}{$t$} & \multirow[t]{2}{*}{ Sig. } \\
\hline & & B & Std. Error & & & \\
\hline \multirow{3}{*}{1} & (Constant) & 23.411 & 3.028 & & 7.730 & .000 \\
\hline & X1 & -.014 & .065 & -.016 & -.223 & .824 \\
\hline & $\mathrm{X} 2$ & .750 & .077 & .693 & 9.715 & .000 \\
\hline
\end{tabular}

Sumber data: Data diolah, 2019 berikut:

Dari hasil analisis regresi linier berganda diatas, dapat diperoleh persamaan sebagai $\mathrm{Y}=23.411+-, 014+0,750+\mathrm{e}$

Berdasarkan persamaan regresi linier berganda tersebut diatas dapat diinterpresetasikan sebagai berikut:

a. Nilai kontanta bernilai positif sebesar 23,411 hal ini menunjukkan apabila variabel keadilan distributif dan keadilan interaksional kompensasi konstan, maka kepuasan kerja sebesar 23,411.

b. Koefisien regresi variabel X1 bernilai negatif sebesar -,014 hal ini menunjukkan bahwa apabila keadilan distributif semakin menurun dengan asumsi variabel lain konstan, makahal tersebut dapat menurunkan kepuasan kerja sebesar -,014.

c. Koefisien regresi variabel X2 bernilai positif sebesar 0,750 hal ini menunjukkan bahwa apabila keadilan interaksional kompensasi semakin baik dengan asumsi variabel lain konstan, maka hal tersebut dapat meningkatkan kepuasan kerja sebesar 0,750 .

\subsection{Hasil Uji Hipotesis}

\subsubsection{Uji F ( Simultan )}

Uji F digunakan untuk menunjukkan apak semua variable bebas yaitu keadilan distributive dan keadilan interaksional kompensasi mempunyai pengaruh signifikan secara bersama-sama (simultan) terhadap kepuasan kerja pegawai. Pengujian hipotesis ini dilakukan dengan menggunaka uji $\mathrm{F}$, dengan cara membandingkan nilai $\mathrm{F}$ hitung hasil analisis regresi pada taraf nyata $a=0,05$.

Tabel 6. Uji simultan

\begin{tabular}{|l|l|l|l|l|l|}
\hline Model & Sum of Squares & Df & Mean Square & F & Sig. \\
\hline Regression & 1242.501 & 2 & 621.250 & 52.543 & $.000^{\mathrm{b}}$ \\
Residual & 1383.366 & 117 & 11.824 & & \\
Total & 2625.867 & 119 & & & \\
\hline
\end{tabular}


Sumber data: Data diolah, 2019

Berdasarkan tabel 6 nilai $F$ sebesar 52,543 dan tingkat signifikansi sebesar $F(0,000)<$ a $=0,05$ maka dapat disimpulkan bahwa variabel keadilan distributif (X1) dan keadilan interaksional kompensasi (X2) secara simultan berpengaruh terhadap kepuasan kerja pegawai $(Y)$.

\subsubsection{Koefisien determinasi (Adjusted R²)}

Untuk mengetahui besarnya kontribusi variable bebas (keadilan distributif dan keadilan interaksional kompensasi (X2) terhadap variable terikat (kepuasan kerja pegawai digunakan nilai Adjusted $\mathrm{R}^{2}$ koefisien dari determinasi digunakan untuk menghitung besarnya suatu pengaruh atau kontribusivariabel bebas terhadap variabel terikat. Dari analisis tersebut yang terlihat pada tabel 7, diperoleh hasil Adjusted R square sebesar 0, 464 .

Tabel 7. Koefisien korelasi dan determinasi

\begin{tabular}{|c|c|c|c|c|c|c|c|}
\hline \multirow[t]{2}{*}{ Model } & \multirow[t]{2}{*}{$\mathrm{R}$} & \multirow[t]{2}{*}{ R Square } & \multirow{2}{*}{$\begin{array}{l}\text { Adjusted } \\
\text { R Square }\end{array}$} & \multirow{2}{*}{$\begin{array}{l}\text { Std. } \\
\text { Error of } \\
\text { the } \\
\text { Estimate }\end{array}$} & \multicolumn{3}{|l|}{ Change Statistics } \\
\hline & & & & & $\begin{array}{l}\mathrm{R} \text { Square } \\
\text { Change }\end{array}$ & F Change & df1 \\
\hline 1 & $.688^{a}$ & .473 & .464 & 3.439 & .473 & 52.543 & 2 \\
\hline
\end{tabular}

Sumber data: Data diolah, 2019

Dari data di atas dapat diketahui bahwa koefisien determinasi Adjusted $\mathrm{R}$ square sebesar 0, 464. Hal ini menunjukkan bahwa variabel keadilan distributif dan keadilan interaksional kompensasi hanya mempengaruhi sebesar $46 \%$ terhadap kepuasan kerja pegawai, Sedangkan sisanya $54 \%$ dipengaruhi oleh variabel lain yang tidak diteliti dalam penelitian ini.

Berdasarkan nilai korelasi sebesar 0,688 hal ini menunjukkan hubungan antara variabel keadilan distributif (X1) dan keadilan interaksional kompensasi (X2) dengan variabel kepuasan kerja pegawai dengan tingkat hubungan Kuat, sesuai dengan tabel pedoman interval koefisien korelasi (sugiyono, 2016).

\subsubsection{Uji t ( Parsial)}

Uji $t$ digunakan untuk mengetahui apakah variable bebas yaitu keadilan distributif dan keadilan interaksional kompensasi secara parsial memiliki pengaruh signifikan terhadap variabel terikat kepuasan kerja pegawai, serta untuk melihat pengaruh dominan terhadap variabel terikat.

\section{Tabel 8.Uji t ( Parsial)}

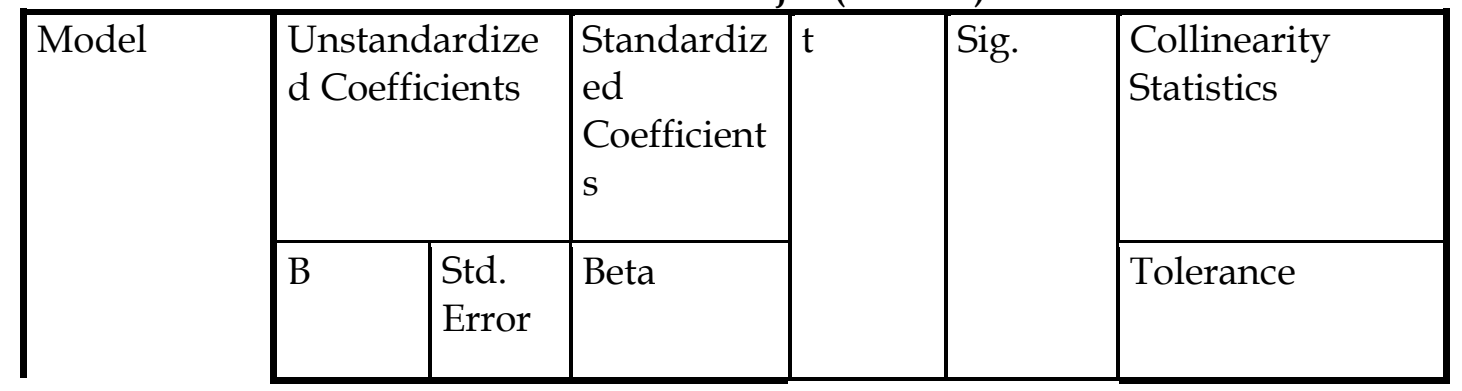




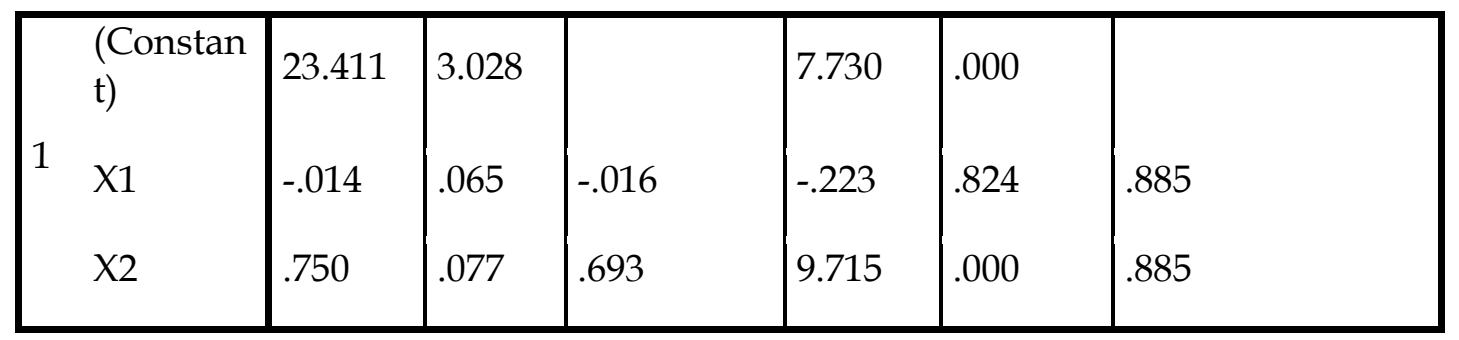

Sumber data: Data diolah, 2019

Berdasrkan tabel 8 bahwa hasil olahan data SPSS versi 20 diatas diperoleh hasil sebagai berikut:

1. Variabel $\mathrm{X} 1$ (keadilan distributif) memiliki nilai $\mathrm{t}$ hitung sebesar $-0,223$ dengan signifikansi sebesar 0,824. Atau sig. $<5 \%(0,824<0,05)$, maka Ho di terima H1 ditolak dan dapat disimpulkan bahwa secara parsial variabel keadilan distributiftidak berpengaruh positif dan signifikan terhadap kepuasan kerja pegawai

2. Variabel X2 (keadilan interaksional kompensasi)memiliki nilai t-hitung sebesar 9,715 dengan signifikansi sebesar 0,000 . Atau sig. $<5 \%(0,000<0,05)$, maka Ho di tolak dan $\mathrm{H} 1$ diterima maka dapat disimpulkan bahwa secara parsial variabel keadilan interaksional kompensasi berpengaruh positif dan signifikan terhadap kepuasan kerja pegawai.

\section{Pengujian hipotesis}

Pengaruh Keadilan distributif terhadap kepuasan kerja

Hasil uji $t$ untuk variabel diperoleh nilai $t$ - hitung sebesar -0,223 dengan nilai $t$ - tabel sebesar 1,983 $(-0,223<1,983)$ dengan nilai signifikansi sebesar 0,824 lebih besar dari 0,05 $(0,824>0,05)$, maka hipotesis yang menyatakan bahwa "Keadilan distributif tidak berpengaruh positif dan signifikan terhadap kepuasan kerja pegawai pada Rumah Sakit PKU Muhammadiyah Bima“ Hipotesis1ditolak" Hal itu dikarenakan jika keadilan distributif kurang baik maka kepuasan kerja pada setiap pegawai akan mengalami penurunan.Hal ini didukung oleh Kristanto, et al 2013.Menunjukkan bahwa keadilan distributif tidak berpengaruh positif dan signifikan terhadap kepuasan kerja.

Pengaruh keadilan interaksional kompensasi terhadap kepuasan kerja

Hasil uji $\mathrm{t}$ untuk variabel diperoleh nilai $\mathrm{t}$ - hitung sebesar 0,9715 dengan nilai $\mathrm{t}$ - tabel sebesar 1,983 $(0,9715>1,983)$ dengan nilai signifikansi sebesar 0,000lebih besar dari 0,05 $(0,000<0,05)$, maka hipotesis yang menyatakan bahwa "Keadilan interaksional kompensasi berpengaruh positif dan signifikan terhadap kepuasan kerja kerja pegawai pada Rumah Sakit PKU Muhammadiyah Bima "Hipotesis 2 diterima"Hal ini mendukung penelitian sebelumnya yang telah diteliti oleh Malik et al., (2011) yang menyatakan bahwa terdapat hubungan yang positif dan signifikan terhadap kepuasan kerja, dimana adanya keramahtamahan dan perhatian antar personal baik dengan atasan maupun dengan sesame pegawai. Selain penelitian yang dilakukan oleh Sutrisna dan Rahyuda (2014) terhadap beberapa para medis di rumah sakit TK 11 Udayana Dempasar memperoleh hasil bahwa keadilan interaksional mempunyai pengaruh positif dan signifikan terhadap kepuasan kerja, karena secara umum keadilan interaksional berkaitan dengan aspek interaksi melalui penyampaian informasi antar personal yang dapat di jadikan pertimbangan strategis dalam menentukan rasa puas dalam bekerja.

Pengaruh Keadilan distributif dan keadilan interaksional kompensasi terhadap kepuasan kerja

Hasil uji F untuk variabel diperoleh nilai F- hitung sebesar 52,543 dengan nilai Ftabel sebesar 3,07 $(52,543>3,07)$ dengan nilai signifikansi sebesar 0,000lebih besar dari 0,05 
$(0,000<0,05)$, Berdasarkan hasil penelitian yang dilakukan dapat diketahui keadilan distributif dan keadilan interaksional kompensasi berpengaruh positif dan signifikan terhadap kepuasan kerja pegawai pada Rumah Sakit PKU Muhammadiyah Bima. "Hipotesis 3 diterima".

\section{KESIMPULAN}

Berdasarkan hasil analisis yang dilakukan pada penelitian ini untuk mengetahui dan menganalisis keadilan distributif dan keadilan interaksional kompensasi terhadap kepuasan kerja pegawai.

1. Berdasarkan hasil penelitian ini bahwa keadilan distributif dankeadilan interaksional kompensasi yang rasakan olehpegawai berpengaruh secara simultan terhadap kepuasan kerja pegawai pada Rumah Sakit PKU Muhammadiyah Bima.

2. Berdasarkan hasil penelitian ini bahwa keadilan distributif tidak berpengaruh positif dan signifikan terhadap kepuasan kerja pegawai pada Rumah Sakit PKU Muhammadiyah Bima.

3. Berdasarkan hasil penelitian ini bahwa keadilan interaksional kompensasi berpengaruh positif dan signifikan terhadap kepuasan kerja pegawai pada Rumah Sakit PKU Muhammadiyah Bima.

\section{Saran}

Saran yang dapat diberikan adalah pihak manajemen dihapkan meyakinkan pegawai bahwa prosedur pendisribusian penghargaan yang telah diterima belum sesuai dengan kesulitan pekerjaan mereka dan seluruh keputusan dilakukan dengan konsisten kepada seluruh pegawai dan diharapkan memperhatikan setiap jenis pekerjaan yang dikerjakan para pegawai tersebut demi kemajuan amal usaha pada Rumah Sakit PKU Muhammadiyah Bimadan menjaga tingkat kepuasan kerja para karyawannya yang nantinya dapat meminimalisir keinginan keluar pegawai.

\section{Keterbatasan}

Dalam melaksanakan penelitian ini, peneliti menyadari bahwa penelitian ini mempunyai keterbatasan, antara lain:

1. Penelitian ini hanya menggunakan metode survey melalui koesioner, tanpa, melakukan wawancara maupun terlibat secara langsung dalam aktivitas instansi, sehingga simpulan yang dikemukakan hanya berdasarkan data yang dikumpulkan melalui instrument secara tertulis.

2. Variabel yang digunakan dalam penelitian hanya keadilan distributif, keadilan interaksional kompensasi dan kepuasan kerja

3. Penelitian ini hanya dilakukakan di salah satu Amal Usaha Muhammadiyah yaitu padaRumah Sakit PKU Muhammadiyah Bima.

\section{DAFTAR KEPUSTAKAAN}

Agungaws waspodo dan lussy minadaniati, 2012. Pengaruh kepuasankerjadan iklim organisasi terhadaporganizationalcitizenshipbehavior(OCB) karyawanpadaPT. Trubus swadaya depok. Jurnalriset manajemen sainsindonesia (JRMSI) |vol.3, no. 1. Jakarta.

Catur Agus Sancoko dan Mutiara S Panggabean, 2015.Pengaruh keadilan organisasi terhadap komitmen organisasional dengan kepuasan kerja sebagai variabel intervening di sekolah santa Ursula BSD. Jurnal MIX, Volume V, No. 1.34-53.

Gusti ayu krisnayanti, 1 Gede Riana, 2015.Pengaruh keadilan organisasi terhadap kepuasan kerja karyawan. E- Jurnal Manajemen Unud, Vol. 4, No. 9, 813-831 1SSN: 
2302-8912.

Jumari, dkk,2013. Pengaruh Budaya Organisasi, Efikasi Diri, dan Kepuasan Kerja Terhadap Kinerja Mengajar Guru SMK Negeri Kecamatan Denpasar Selatan,eJurnal Program Pascasarjana Universitas Pendidikan Ganesha Program Studi Administrasi Pendidikan, Volume 4 No.1 Tahun. ISSN : 2460-1497.

Luthfi irawan dan Ketut Sudarma, 2016.Pengaruh keadilan distributive dan keadilan prosedural pada komitmen afektif melalui kepuasan kerja.Manajement analysis journal 5 (2).

Nadiri, Halil., and Tanova, Cem. 2010. An Investigation Of The Role Of Justice In Turnover Intentions, Job Satisfaction, And Organizational Citizenship Behavior In Hospitality Industry. International Journal of HospitalityManagement. 29, pp:33-41.

NimrahRahmayantiYusuf, DeddyT. ThahirHaning,2016. Asosiasikeadilanorganisasidengankepuasankerjapegawairumahsakit universitas hasanuddinkotamakassar. Jurnal j. Analisis vol.5 No. 2: 181-186. ISSN 2302-6340.

Majang palupi, heru kurnianto Tjahjono dan Rafika nuri, 2014.Pengaruh keadilan distributif karir dan keadilan prosedural karir terhadap perilaku retaliasi karyawan swasta di daerah istemewa Yogyakarta sebagai variabel pemediasian.Jurnal Universitas paramedina Vol. 11 No. 2.

Mahmudah Enny Widyaningrum,2010., Pengaruh keadilan organisasi terhadap kepuasan kerja, komitmen dan organizational citizenship behavior pegawai (studi kasus di rumah sakit bersalin pura raharja surabaya) tahun 2009, Tahun XX, No. 1 April 2010.Majalah Ekonomi.

Puryana, P.P,Priyono, 2017."Menurunkan Intense Turnover Melalui Keadilan Organisasi dan Kepuasan Kerja", jurnal Dosen STIE STEMBI - Bandung Business SchoolURL:www.stiestembi.ac.idISSN : Vol.1693-4474.

Putra, 2018. Pengaruh keadilan organisasi terhadap kepuasan kerja dan komitmen organisasional di hotel Rama Phala Ubud. E-Jurnal Manajemen Unud, Vol. 7, No. 4: 2010-2040. 1SSN 2302- 8912.

R. Philipus Lewis, 2013. Keadilan distributif, keadilan prosedural, keadilan interaksional kompensasi dan komitmen karyawan. Jurnal JRMB, Volume 8, No.1 Juni

Singgih tiwut Atmojo dan Heru Kurnianto Tjahjono, 2016.Pengaruh keadilan distributif dan procedural konpensasi terhadap kepuasan kerja dan kinerja paramedis di rumah sakit. Vol. 7 No. 1 Februari .JBTI.

Sugiono, 2016. Metode penelitian kuantitatif Kualitatif dan Kombinasi ( Mixed Methods). Bandung: Alfabeta.

Sutrisna dan rahyuda, 2014.Pengaruh keadilan distributive, procedural dan interaksional terhadap kepuasan kerja dan komitmen organisasi pada paramedic di rumah sakit II udayana Denpasar. 
NATIONALLY ACCREDITED JOURNAL - DECREE NO. 21/E/KPT/2018 